Revue bibliographique pour le domaine irano-aryen

Volume 32-33 | 2013

Comptes rendus des publications de 2009-2010

\title{
Giorgio Rota. Safavid Envoys in Venice
}

Colin P. Mitchell and Angelo-Michele Piemontese

\section{(2) OpenEdition}

\section{Journals}

Electronic version

URL: http://journals.openedition.org/abstractairanica/40753

DOI: 10.4000/abstractairanica.40753

ISSN: 1961-960X

\section{Publisher:}

CNRS (UMR 7528 Mondes iraniens et indiens), Éditions de l'IFRI

\section{Printed version}

Date of publication: 1 December 2013

ISSN: 0240-8910

\section{Electronic reference}

Colin P. Mitchell and Angelo-Michele Piemontese, «Giorgio Rota. Safavid Envoys in Venice », Abstracta Iranica [Online], Volume 32-33 | 2013, document 257, Online since 01 July 2016, connection on 27 September 2020. URL : http://journals.openedition.org/abstractairanica/40753 ; DOI : https://doi.org/ 10.4000/abstractairanica.40753

This text was automatically generated on 27 September 2020

Tous droits réservés 


\title{
Giorgio Rota. Safavid Envoys in Venice
}

\author{
Colin P. Mitchell and Angelo-Michele Piemontese
}

\section{REFERENCES}

Giorgio Rota. « Safavid Envoys in Venice », in : Ralph Kauz, Giorgio Rota, Jan Paul Niederkorn, eds., Diplomatisches Zeremoniell in Europa und im mittleren Osten in der frühen Neuzeit. Wien, Verlag der Österreichischen Akademie der Wissenschaften, 2009, p. 213-249. (Philos-Hist. Kl. Sitzungsberichte, Band 796. Archiv für österreichische Geschichte, Band 141)

1 This article is part of a larger collection of articles that shed light of the diplomatic world as it took shape between the Middle East and Europe during the early modern period. Giorgio Rota, drawing on a rich reservoir of published texts, documents and manuscripts in Italy (specifically Venice), provides a thorough, insightful study of how the Venetians practiced diplomacy in relations with envoys and ambassadors from Safavid Iran during the 16th and early 17th centuries. There were approximately 13 or 14 missions from the Safavid court to Venice, with a wide range of agendas (particularly, trade and a potential alliance against the Ottomans). Rota focuses on four

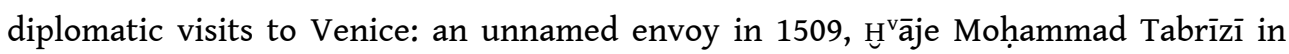
1580, Asad Beg in 1600 and Fathī Beg in 1603. These envoys were by and large mercantile "middlemen", and the Venetians responded to these overtures as a function of the political context. The author provides considerable details (from Italian sources) about the accounts of each of these missions. In Rota's opinion, the most important visit in terms of the Venetian response and interest was Fathī Beg's. Shortly after this visit, the Venetian senate commissioned a large painting depicting the meeting between the Safavid envoy and the Venetian doge. It currently hangs in the Sala delle Quattro Porte of Palazzo Ducale, the great hall where visiting dignitaries waited before entering the Collegio itself. This painting shares the Sala delle Quattro Porte with two other major paintings: The Arrival of Henry III at the Lido (late 16th century) and The 
Ambassadors of Nuremberg in the Presence of the Doge (by the same artist as the SafavidDoge painting). It would have been helpful had Rota included a reproduction of the painting in his article. The article contains several indices, one of them a transliteration of a Persian Safavid letter penned by Hatem Beg Ordūbādī, a minister who served Šāh 'Abbās between 1591 and 1610. This original letter is currently preserved in the State Papers Collection in Venice.

2 L'A. présente sous son vrai jour l'envergure des missions safavides qui ont visité Venise entre le $\mathrm{XVI}^{e}$ et le $\mathrm{XVII}^{\mathrm{e}}$ siècle. Il brosse le tableau des circonstances historiques, les relations bilatérales et la situation internationale, qui donnaient lieu à la réception, suivant le cérémonial de la République vénitien, ainsi que le but de la mission et le rang des envoyés. Ils étaient pour la plupart marchands et souvent des chrétiens d'origine étrangère au service du royaume safavide. Parmi les 13 ou 14 missions safavides à Venise on ne peut pas considérer comme de réels ambassadeurs pas plus de quatre ou cinq des envoyés (p. 216). L'A. traite d'une façon détaillée quatre missions : la première confiée à deux envoyés inconnus (1509), la deuxième accomplie par Hु̄āje Moḥammad Tabrīzī (1580), celle du marchand Asad Beyg (1600) et l'autre du marchand Fathī Beyg (1603). Alors la rencontre du Doge avec les envoyés persans fut représentée, probablement par le peintre Gabriele Caliari (env. 1604) : c'est le tableau célèbre placé dans la Salle des Quatres Portes du Palais Ducal (p. 229-233). À cause de complications politiques Venise avait refusé sa porte à la mission guidée par Ḥoseyn-'Alī Ḩān Bayāt et Anthony Sherley, quoique ce dernier fût entré dans le territoire vénitien (1600). Les relations bilatérales, brillants à l'époque de Šāh 'Abbās I, déclinèrent pendant la deuxième moitié du XVII ${ }^{\mathrm{e}}$ s., par suite des guerres de Candia et de la Sainte Ligue : « the aim of creating an anti-Ottoman military alliance was never achieved » (p. 215).

\section{AUTHORS}

COLIN P. MITCHELL

Dalhousie University, Canada

ANGELO-MICHELE PIEMONTESE

Università la Sapienza, Rome 